\title{
New record and distribution map of Parmotrema rubifaciens (Parmeliaceae, Ascomycota) in the Neotropics
}

\author{
Andrea Michlig*, María P. Rodríguez and Lidia I. Ferraro \\ Instituto de Botánica del Nordeste (IBONE-UNNE-CONICET), Sargento Cabral 2131, CC 209, CP 3400, Corrientes, Argentina \\ * Corresponding author. E-mail: andrea.michlig@yahoo.com
}

\begin{abstract}
Parmotrema rubifaciens is recorded in this paper for the first time for Paraguay, expanding its known geographic distribution approximately 430 $\mathrm{km}$ southeast from its nearest locality. The species is characterized, illustrated, and compared with most related taxa. In addition, a map of its geographic distribution in the Neotropics is presented.
\end{abstract}

Key words: Paraguay, Agua Dulce, norstictic acid, dry forests, Parmotrema cristiferum, P. dilatatum, P. gardneri

Lichen biota of Paraguay has been poorly studied in South America. The first revision of lichens from Paraguay was undertaken in the late nineteenth century by Müller (1888), who identified 248 species of which 73 were described as new to science. Subsequently, in the early twentieth century, Malme (1897, 1924, 1925, 1926, 1927, 1928, 1929, 1934a-b-c-d, 1936, 1937) documented species of several groups of lichens increasing the knowledge available until then.

Thirty species of Parmotrema A. Massal. are currently known from Paraguay, a relatively low number considering it is one of the larger genera within Parmeliaceae, comprising ca. 350 species with center of distribution in the tropical regions of the world (Blanco et al. 2005; Crespo et al. 2010). Müller (1888) recorded the first 4 species of this genus of foliose lichens from Paraguay, followed by Lynge (1914), who added 4 species. Most Parmotrema reports were recorded between 1959 and 1976, as part of several monographic revisions made by Hale (Hale 1959, 1960, 1965, 1974b, 1976; Hale and Kurokawa 1964). Ferraro (1990) listed 15 species of Parmotrema among other genera of Parmeliaceae in an article about the collections of A. Schinini and E. Bordas from Paraguay. Other authors that contributed to the knowledge of this genus in Paraguay are Osorio (1970), Egan et al. (2005), and Michlig and Ferraro (2012). Below, we present a new record of Parmotrema rubifaciens (Hale)
Hale found in Paraguay during a revision of the material from the CTES herbarium.

Studied material was collected by A. Schinini (collection number 19661; CTES) in the Agua Dulce locality, towards the northwestern region of the country, in a xerophytic forest, on Ruprechtia sp. (Table 1, Figures 1-5). Morphological analysis was carried out based on observations of macroscopic and microscopic characters using stereoscopic and light microscopes (Leica MZ6 and Leica CME, respectively). Pycnidia were sectioned by hand with a razor blade and then mounted in $5 \% \mathrm{KOH}$ and $1 \%$ phloxine for examination. The identification of lichen substances was made with spot tests with $10 \%$ $\mathrm{KOH}(\mathrm{K})$, sodium hypochlorite $(\mathrm{C})$, and $\mathrm{K}$ followed by $\mathrm{C}$ (KC), UV fluorescence, and thin layer chromatography (TLC) with solvent $C$, by comparison with authentic samples (Orange et al. 2010; White and James 1985).

Parmotrema rubifaciens was originally erected as a member of Parmelia Ach., subgenus Amphigymnia (Vain.) C. W. Dodge, section Amphigymnia Vain. (Hale 1965), which was later transferred to the genus Parmotrema by Hale (1974a). It is distinguished from other species of the genus by the combination of the following characters: eciliate lobe margins, marginal to submarginal soralia, and medullary norstictic acid ( $\mathrm{K}+$ yellow turning orange with rusty-red needle-like crystals visible under the microscope).

The lobes are irregularly branched, partially imbricate, plane in distal parts, turning sinuate and ascendant

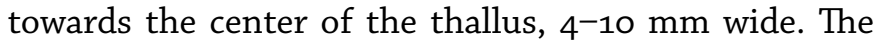
upper surface is smooth to rugose towards the center, sublustrose, irregularly cracked and emaculate, with flaking cortex in some areas. The medulla is mostly white with an orange pigment in some small areas towards the lower surface, or even occasionally in soralia. The lower surface is black with a black to brown, broad and naked margin (Figure 2), with scarce, simple to sometimes irregular black rhizines, which are distributed in groups. The soralia are marginal to submarginal, linear, 


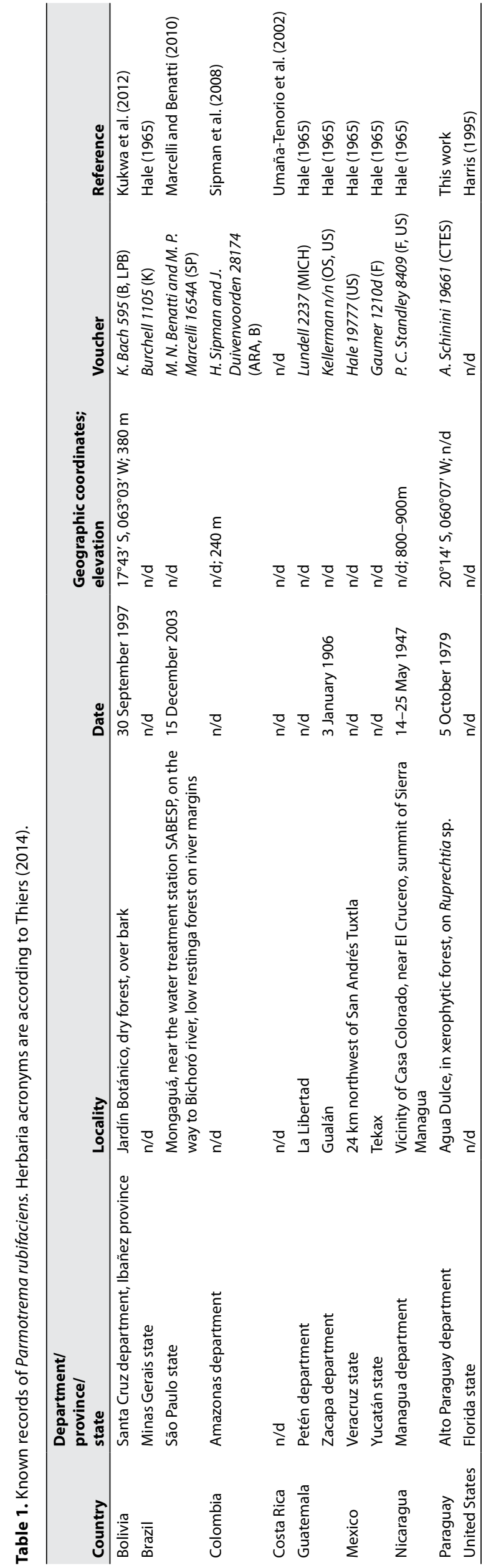

usually thick, turning lobes very sinuous towards the center of the thallus (Figures 1, 3 and 4), with farinose to granular soredia. In some areas it may also develop laminal orbicular to capitate soralia, which are solitary or confluent (Figure 5). Apothecia are absent in the studied material, and although pycnidia were observed (not reported before for the species), they were empty. This species produces cortical atranorin, and medullary norstictic (major) and connorstictic acids (trace). Although the presence of connorstictic acid was not detected in its original description (Hale 1965), it was confirmed by Marcelli and Benatti (2010). Kukwa et al. (2012) also reported lecanoric acid in Bolivian material. There is not much information available about its ecology in literature. It is probably an exclusively corticolous species, as seen in this collection and reported also by previous authors (Kukwa et al. 2012; Marcelli and Benatti 2010).

Parmotrema rubifaciens is the only sorediate species of the genus with norstictic acid known so far from Paraguay. Parmotrema perforatum (Jacq.) A. Massal. has medullary norstictic acid, but lacks vegetative propagules (Hale 1965; Müller 1888). The species resembles Parmotrema cristiferum (Taylor) Hale, a cosmopolitan species widely distributed in tropical and subtropical regions, cited also from Paraguay (Ferraro 1990), which shows a similar configuration of soralia but differs in its medullary chemistry by producing salazinic acid ( $\mathrm{K}+$ yellow turning red, without rustyred needle-like crystals visible under the microscope). Some authors also mentioned the presence of scarce cilia in a few specimens of $P$. cristiferum, structures not observed in the studied material (Elix 1994; Marcelli and Benatti 2010). Other morphologically related species are Parmotrema dilatatum (Vain.) Hale and Parmotrema gardneri (C.W. Dodge) Sérus. recorded also from Paraguay (Ferraro 1990; Michlig and Ferraro 2012). In both species, the soralia are narrower and clearly differ from $P$. rubifaciens in their medullary chemistry, as they produce protocetraric acid, associated also with echinocarpic acid in P. dilatatum.

Parmotrema rubifaciens is an exclusively American species known only from scattered records in the Neotropical region (Figure 6). It was initially described from Nicaragua by Hale (1965), who also studied additional material from Guatemala, Mexico, and Brazil. Since then, there have been neither new records nor new information available of this species for over three decades, when it was recorded by Harris (1995) from United States. More recently, the species was recorded from Costa Rica (Umaña Tenorio et al. 2002), southern Colombia (Sipman et al. 2008), southeastern Brazil (Marcelli and Benatti 2010), and Bolivia (Kukwa et al. 2012). Its geographic distribution is here expanded to northwestern Paraguay. 


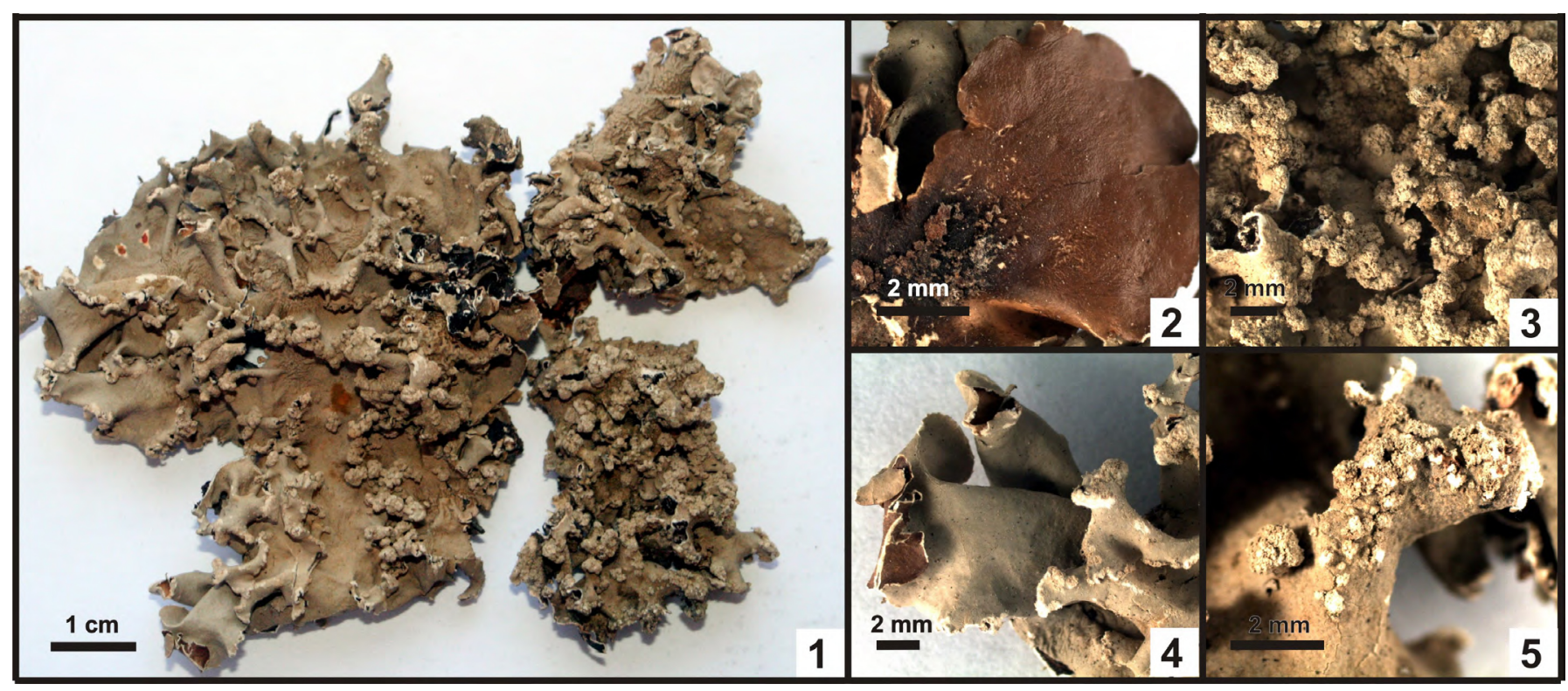

Figures 1-5. Parmotrema rubifaciens (Hale) Hale. 1: Complete thallus. 2: Erhizinate margin in the lower surface. 3: Soralia at the center of the thallus. 4: Marginal soralia toward the periphery of the thallus. 5: Laminal soralia.

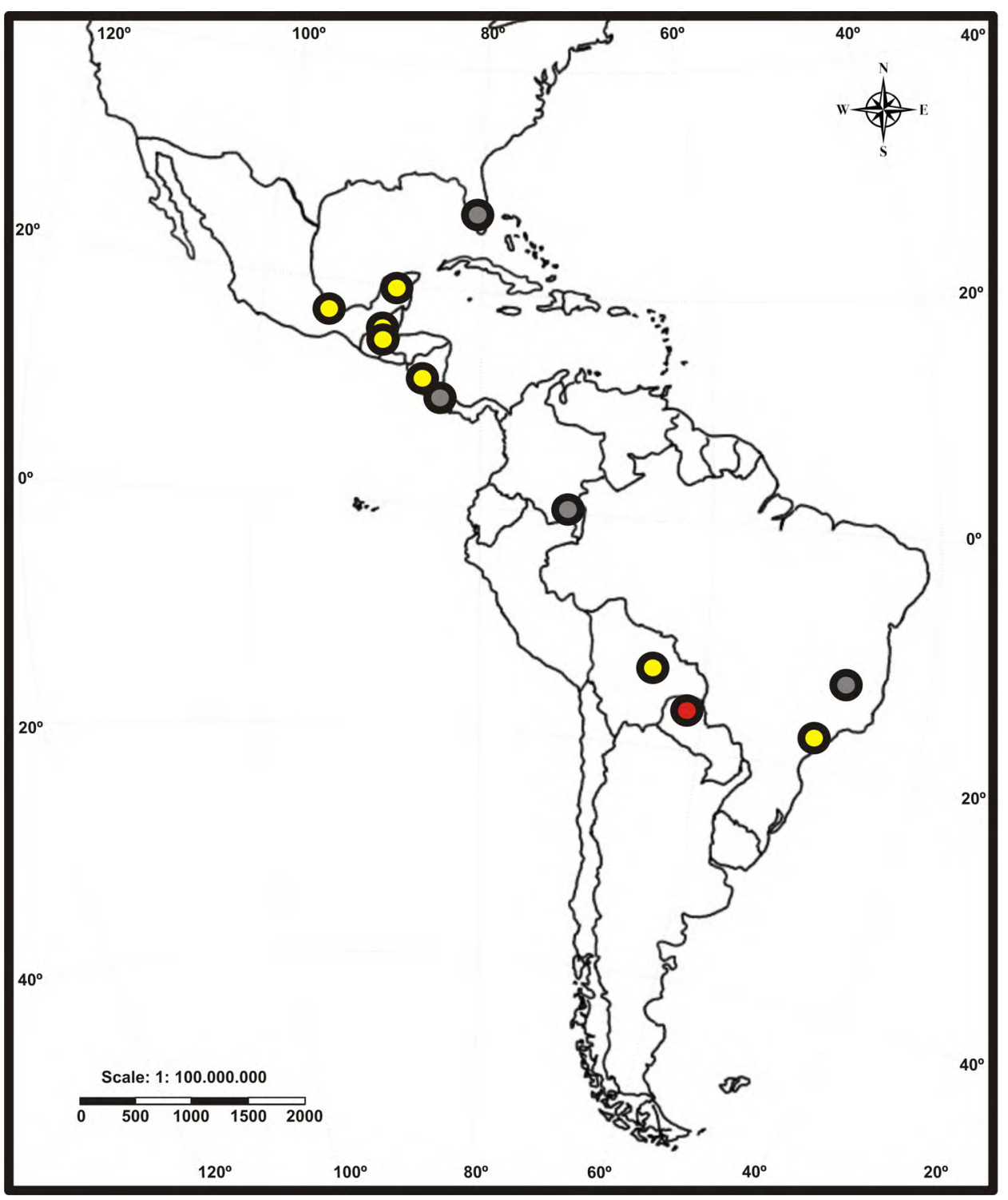

Figure 6. Geographical distribution of Parmotrema rubifaciens in the Neotropics based on revised material and literature (Table 1). The red dot corresponds to the new record and gray dots indicate collections with uncertain localities. 
The geographic distribution of $P$. rubifaciens is shown in Figure 6, based on studied material and records available in the literature (Table 1). According to this information, its distribution pattern seems to be approximately coincident with tropical and subtropical dry forests (TDFs hereafter) in America (Miles et al. 2006; Portillo-Quintero and Sánchez-Azofeifa 2010). In South America, where TDFs are particularly well represented (Miles et al. 2006), its distribution is mostly overlapped with the Pleistocenic Arc of the Tropical Seasonal Forests Region, which was defined by the distribution of many woody species of deciduous and semideciduous forests (Prado 200o; Oakley and Prado 2011).

Although the exact sites where some of these collections were found are unknown (Hale 1965; Harris 1995; Umaña et al. 2002; Sipman et al. 2008), considering the distribution of TDFs in America it is probable that most of them have been collected in environments with those ecological conditions. The material reported by Hale (1965) from Brazil was found in Minas Gerais state, which has extensive areas covered by TDFs, that mostly belong to the Cerrado biome (Oliveira-Filho and Ratter 2002), and the much drier Caatinga, which is restricted to the northern region of the state (Queiroz 2009). The collection cited by Harris (1995) from Florida in United Sates could have been collected towards the southernmost region of the state, where TDFs are confined (Gillespie et al. 2006; Pennington et al. 2006), while the record from Costa Rica might have been found towards the northwestern region of the country, where TDFs are located (Gillespie et al. 2000). Nevertheless, the collection reported by Sipman et al. (2008) from southern Colombia appears to be excluded from TDFs' range extension, since this type of vegetation is situated between the interandean valleys of Magdalena and Cauca rivers and in Caribbean plain regions, towards the northwestern region of the country (Ruiz Linares and Fandiño Orozco 2009).

The distribution of TDFs in South America was recently considered as a possible explanation for the geographic patterns of other fungal species, which were also scarcely collected (Romero et al. 2012; Robledo et al. 2014). Even though the distribution of epiphytic lichens is not always correlated with that of the plants (Will-Wolf et al. 2004), it would be interesting to analyze other distribution patterns to establish which species might have similar ecological preferences, and to detect possible endemisms. This might constitute an important contribution, as these forests are currently considered one of the ecorregions prioritized for conservation (Olson and Dinerstein 2002), since they harbor a high biodiversity, including an appreciable level of genera and species endemism (Prado 2000; Portillo-Quintero and Sánchez-Azofeifa 2010).

\section{ACKNOWLEDGEMENTS}

The authors wish to thank the Consejo Nacional de Investigaciones Científicas y Técnicas (CONICET) and the Secretaría General de Ciencia y Técnica (SGCyTUNNE) for financial support. AM and MPR are scholarships holders of CONICET and SGCyT-UNNE, respectively. Two anonymous reviewers are also thanked for their useful comments.

\section{LITERATURE CITED}

Blanco, O., A. Crespo, P.K. Divakar, J.A. Elix and H.T. Lumbsch. 2005. Molecular phylogeny of parmotremoid lichens (Ascomycota, Parmeliaceae). Mycologia 97(1): 150-159. doi: 10.3852/ mycologia.97.1.150

Crespo, A., F. Kauff, P.K. Divakar, R. del Prado, S. Pérez-Ortega, G. Amo de Paz, Z. Ferencova, O. Blanco, B. Roca-Valiente, J. Núñez-Zapata, P. Cubas, A. Argüello, J.A. Elix, T.L. Esslinger, D.L. Hawksworth, A. Millanes, M.C. Molina, M. Wedin, T. Ahti, A. Aptroot, E. Barreno, F. Bungartz, S. Calvelo, M. Candan, M. Cole, D. Ertz, B. Goffinet, L. Lindblom, R. Lücking, F. Lutzoni, J.E. Mattsson, M.I. Messuti, J. Miadlikowska, M. Piercey-Normore, V.J. Rico, H.J.M. Sipman, I. Schmitt, T. Spribille, A. Thell, G. Thor, D.K. Upreti and H.T. Lumbsch. 2010. Phylogenetic generic classification of parmelioid lichens (Parmeliaceae, Ascomycota) based on molecular, morphological and chemical evidence. Taxon 59(6): 1735-1753.

Elix, J.A. 1994. Parmotrema; 140-162, in: A.E. Orchard (ed.). Lichens - Lecanorales 2, Parmeliaceae, Flora of Australia 55. Canberra: Australia Government Publishing Service.

Egan, R.S., R. Harms and T. Widhelm. 2005. Studies on the lichen Parmotrema rigidum s. lat. from North and South America. The Bryologist 108(3): 402-405. doi: 10.1639/0007-2745(2005)108 [0402:SOTLPR]2.0.CO;2

Ferraro, L.I. 1990. Contribución al conocimiento de los líquenes de Paraguay, colecciones de A. Schinini y de E. Bordas; pp. 655-670, in: R. Spichiger and L. Ramella (eds.). Notulae ad Floram paraquaiensem, 24-25. Candollea 45(2).

Gillespie, T.W., A. Grijalva and C.N. Farris. 200o. Diversity, composition, and structure of tropical dry forests in Central America. Plant Ecology 147: 27-47. doi: 10.1023/A:1009848525399

Gillespie, T.W., B.R. Zutta, M.K. Early and S. Saatchi. 2006. Predicting and quantifying the structure of tropical dry forests in South Florida and the Neotropics using spaceborne imagery. Global Ecology and Biogeography 15: 225-236. doi: 10.1111/j.1466-8238. 2005.00203.X

Hale, M.E. 1959. New or interesting species of Parmelia in North America. The Bryologist 62(1): 16-24. doi: 10.2307/3240403

Hale, M.E. 1960. A revision of the South American species of Parmelia determined by Lynge. Contributions from the United States National Herbarium 36(1): 1-41.

Hale, M.E. 1965. A monograph of the Parmelia subgenus Amphigymnia. Contributions from the United States National Herbarium 36(5): 193-358.

Hale, M.E. 1974a. New combinations in the lichen genus Parmotrema Massalongo. Phytologia 28(4): 334-339.

Hale, M.E. 1974b. Notes on species of Parmotrema (lichenes: Parmeliaceae) containing yellow pigments. Mycotaxon 1(2): 105-116.

Hale, M.E. 1976. A monograph of the lichen genus Parmelina Hale (Parmeliaceae). Smithsonian Contributions to Botany 33: 1-6o.

Hale, M.E. and S. Kurokawa. 1964. Studies on Parmelia subgenus Parmelia. Contributions from the United States National Herbarium 36(4): 121-191.

Harris, R.C. 1995. More Florida lichens. Including the 10 Cent Tour 
of the Pyrenolichens. New York, Bronx: Published by the author, New York Botanical Garden. 192 pp.

Lynge, B. 1914. Die Fletchen der ersten Regnellschen Expedition. Die Gattungen Pseudoparmelia gen. nov. und Parmelia Ach. Arkiv för Botanik 13: 1-172.

Kukwa, M., K. Bach, H.J.M. Sipman and A. Flakus. 2012. Thirty-six species of the lichen genus Parmotrema (Lecanorales, Ascomycota) new to Bolivia. Polish Botanical Journal 57(1): 243-257.

Malme, G.O.A. 1897. Die Fletchen der ersten Regnell'schen Expedition. I. Einleitung. Die Gattung Pyxine (FR.) Nyl. Bihang til Kongliga Svenska Vetenskaps-Akademiens handlingar 23(13): 1-52.

Malme, G.O.A. 1924. Die Collematazeen des Regnellschen Herbars. Arkiv för Botanik 19(8): 1-29.

Malme, G.O.A. 1925. Die Pannariazeen des Regnellschen Herbars. Arkiv för Botanik 20A, 3: 1-23.

Malme, G.O.A. 1926. Lichenes blasteniospori Herbarii Regnelliani. Arkiv för Botanik 20A, 9: 1-51.

Malme, G.O.A. 1927. Buelliae itineris Regnelliani primi. Arkiv för Botanik 21A, 14: 1-42.

Malme, G.O.A. 1928. Pyrenula eet Anthracothecia Herbarii Regnelliani. Arkiv för Botanik 22A, 11: 1-40.

Malme, G.O.A. 1929. Porina eet Phylloporinae in Itinere Regnelliano primo collectae. Arkiv för Botanik 23A, 1: 1-37.

Malme, G.O.A. 1934a. Die Stictazeen der ersten Regnellschen Expedition. Arkiv för Botanik 26A, 14: 1-18.

Malme, G.O.A. 1934b. Die Gyalectazeen der ersten Regnellschen Expedition. Arkiv för Botanik 26A, 13: 1-10.

Malme, G.O.A. 1934c. Die Ramalinen der ersten Regnellschen Expedition. Arkiv för Botanik 26A, 12: 1-9.

Malme, G.O.A. 1934d. Bacidiae Itineris Regnelliani primi. Arkiv för Botanik 27A, 5: 1-40.

Malme, G.O.A. 1936. Pertusariae Expeditionis Regnellianae primae. Arkiv för Botanik 28A, 9: 1-27.

Malme, G.O.A. 1937. Lichenes nonnulli in Expeditione Regnelliana prima collecti. Arkiv för Botanik 29A, 6: 1-35.

Marcelli, M.P. and M.N. Benatti. 2010. Espécies de Parmotrema (Parmeliaceae, Ascomycota) do litoral centro-sul do Estado de São Paulo II. Grupos químicos norstíctico e salazínico. Acta Botânica Brasilica 24(1): 153-168. doi: 10.1590/So102-33062010000100015

Michlig, A. and L. Ferraro. 2012. Nuevos registros de especies sorediadas de Parmotrema con ácido protocetrárico (Parmeliaceae, Ascomycota) en el sur de Sudamérica. Darwiniana 50(2): 323-331. http://www.ojs.darwin.edu.ar/index.php/darwiniana/article/ view/434

Miles, L., A.C. Newton, R.S. DeFries, C. Ravilious, I. May, S. Blyth, V. Kapos and J.E. Gordon. 2006. A global overview of the conservation status of tropical dry forests. Journal of Biogeography 33: 491-505. doi: 10.1111/j.1365-2699.2005.01424.x

Müller, J. 1888. Lichenes paraguayenses. Revue Mycologique (Toulouse) 1(38): 52-68.

Oakley, L.J. and D.E. Prado. 2011. El Dominio de los Bosques Estacionales Neotropicales y la presencia del Arco Pleistocénico en la República del Paraguay. Rojasiana 10(1): 55-75.

Oliveira-Filho, A.T. and J.A. Ratter. 2002. Vegetation physiognomies and woody flora of the Cerrado biome; pp. 91-120, in: P.S. Oliveira and R.J. Marquis (eds.). The Cerrados of Brazil: ecology and natural history of neotropical savanna. New York: Columbia University Press.

Olson, D.M. and E. Dinerstein. 2002. The Global 200: priority ecoregions for global conservation. Annals of the Missouri Botanical Garden 89: 199-224. doi: 10.2307/3298564

Orange, A., P.W. James and F.J. White. 2010. Microchemical methods for the identification of lichens. 2nd edition. British Lichen Society. $101 \mathrm{pp}$.

Osorio, H.S. 1970. Lichens from Cantera, South Paraguay. Comunicaciones Botánicas del Museo de Historia Natural de Montevideo 4(50): 1-3.

Pennington, R.T., G.P. Lewis and J.A. Ratter. 2006. An overview of the plant diversity, biogeography and conservation of Neotropical savannas and seasonally dry forests; pp. 1-30, in R.T. Pennington, G.P. Lewis and J.A. Ratter (eds.). Neotropical Savannas and Seasonally Dry Forests: Plant diversity, biogeography, and conservation. Florida: CRC Press, Taylor and Francis Group.

Portillo-Quintero, C.A. and G.A. Sánchez-Azofeifa. 2010. Extent and conservation of tropical dry forests in the Americas. Biological Conservation 143: 144-155. doi: 10.1016/j.biocon.2009.09.020

Prado, D.E. 200o. Seasonally dry forests of tropical South America: from forgotten ecosystems to a new phytogeographic unit. Edinburgh Journal of Botany 57(3): 437-461. doi: 10.1017/ sog6042860000041x

Queiroz, L.P. 2009. Leguminosas da Caatinga. Feira de Santana: Universidade Estadual de Feira de Santana. Kew: Royal Botanic Gardens. 443 pp.

Robledo, G.L., E.M. Giorgio, C.R.P. Franco, O. Popoff and C. Decock. 2014. Gyrodontium sacchari (Spreng.: Fr.) Hjortstam (Boletales, Basidiomycota) in America: new records and its geographic distribution. Check List 10(6): 1514-1519. doi: 10.15560/10.6.1514

Romero, A.I., G. Robledo, K.F. LoBuglio and D.H. Pfister. 2012. Rickiella edulis and its phylogenetic relationships within Sarcoscyphaceae. Kurtziana 37(1): 79-89. http://ref.scielo.org/nm84cr

Ruiz Linares, J. and M.C. Fandiño Orozco. 2009. Estado del bosque seco tropical e importancia relativa de su flora leñosa, islas de la Vieja Providencia y Santa Catalina, Colombia, Caribe suroccidental. Revista de la Academia Colombiana de Ciencias Exactas, Físicas y Naturales 33(126): 5-15.

Sipman, H.J.M., W. Hekking and C.J. Aguirre. 2008. Checklist of lichenized and lichenicolous fungi from Colombia. Biblioteca José Jerónimo Triana 20: 1-242.

Thiers, B. 2014. Index Herbariorum: A global directory of public herbaria and associated staff. New York Botanical Garden's Virtual Herbarium. Accessed at http://sweetgum.nybg.org/ih, 10 February 2015.

Umaña Tenorio, L., H.J.M. Sipman and R. Lücking. 2002. Preliminary checklist of lichens from Costa Rica, Version 1.2. The Field Museum. Accessed at http://archive.fieldmuseum.org/ ticolichen/checklist.html, 15 June 2015.

White, F.J. and P.W. James. 1985. A new guide to microchemical techniques for the identification of lichen substances. Bulletin, British Lichen Society 57 (suppl.): 1-41.

Will-Wolf, S., D.L. Hawksworth, B. McCune, R. Rosentreter and H.J.M. Sipman. 2004. Lichenized fungi; pp. 173-195, in: G.M. Mueller, G.F. Bills and M.S. Foster (eds.). Biodiversity of Fungi: Inventory and monitoring methods. Burlington, San Diego and London: Elsevier Academic Press.

Authors' contribution statement: AM wrote the manuscript, took the photographs and prepared the map; MPR prepared the figures and table; LIF collected data for introduction and funded this study. AM, MPR and LIF identified the studied material.

\footnotetext{
Received: 6 March 2015

Accepted: 28 August 2015

Academic editor: Gerardo Lucio Robledo
} 